\title{
Mary Kaasiku ja Gustav Kallasto rahvaluulekogu ning kirjavahetus
}

\author{
Ave Goršič \\ Eesti Kirjandusmuuseumi Eesti Rahvaluule Arhiivi teadur \\ ave.gorsic@folklore.ee
}

\begin{abstract}
Teesid: Eesti Kirjandusmuuseumi Eesti Rahvaluule Arhiivi hallatava Eesti folkloristika ajaloo materjalide (EFAM) hulgas on ka nõukogudeaegne kirjavahetuse kogu - arhiivi ehk toonase rahvaluuleosakonna ja kaastööliste vahelised kirjad, mis ei läinud erinevatel põhjustel käsikirjadesse ehk põhikogusse, vaid jäeti eraldi. See kirjavahetus on oma aja, tõekspidamiste ja töövõtete andmekaev, sealjuures ka selles osas, mis puudutab avameelseid teateid nii kaastööliste kui muuseumitöötajate tervise kohta, rahvameditsiinilisest materjalist rääkimata. Artiklis vaadeldakse tervisliku seisundi kajastamist kaastööliste kirjades üldiselt ning lähemalt Virumaa kaastööliste Mary Kaasiku ja Gustav Kallasto panust rahvameditsiini andmete kogumisse, kuid ka usalduslikkust folkloristide suhtes isiklikku tervist puudutava info jagamisel nii pärimuspalade kommentaaridena kui ka kirjades rahvaluuleosakonnale.
\end{abstract}

Märksõnad: andmekogu, kirjavahetus, nõukogude aeg, (rahva)meditsiin, tervis

Käesoleva artikli laiemaks allikmaterjaliks on Fr. R. Kreutzwaldi nimelise Riikliku Kirjandusmuuseumi rahvaluule osakonna (RO) ehk Eesti Kirjandusmuuseumi (EKM) Eesti Rahvaluule Arhiivi nõukogudeaegne kirjavahetuskogu, mis koosneb ligi 400 isiku kirjadest, postkaartidest, mittefolkloorsetest materjalidest ning samuti rahvaluule osakonna töötajate vastuste või teadete ärakirjadest kaastöölistele. Kogu maht on hinnanguliselt 4000 lehekülge $^{1}$ ning hõlmab peamiselt vahemikku alates 1950. aastatest kuni 1990. aastate esimese pooleni. Kirjavahetuskogu viiteks on EFAM, RO - Eesti folkloristika ajaloo materjalid EKM Eesti Rahvaluule Arhiivis, Riikliku Kirjandusmuuseumi rahvaluule osakonna kirjavahetus korrespondentidega. Teiseks on vaatluse all Virumaa korrespondentide Mary Kaasiku ja Gustav Kallasto kaastööd osakonnale, ennekõike nende kogutud rahvameditsiiniline materjal, mis on talletatud RKM II seerias. Lisaks viidatakse infole korrespondendikaartidelt. Kolmandaks keskendub artikkel Kaasiku ja Kallasto kirjavahetusele arhiiviga, ennekõike terviseteemadele nende kaaskirjades - kuivõrd avatud olid kaastöölised oma tervisest rääkides ning millisel määral jõudis isiklik teadmine ravimisest kogutud materjalide hulka.

Kirjadel on arhiivimaterjalina omaette väärtus, kirjad on ühteaegu nii ajastudokumendid kui ka avavad isiklikku elu (Annuk 2004: 44), säilitades mälu 
ja loomise aega (Annuk 2006a: 42). Kirjad on muutunud osaks uurimisallikatest, olles ühtlasi enam kui lihtsalt faktide allikad (Stanley 2004: 211; Annuk 2006a: 40). Eesti Kirjandusmuuseumis on avaldatud ja uuritud väga mitmeid kultuurilooliselt olulisi kirjavahetusi (Kirss 2019: 225; Hinrikus \& Kirss 2019). Ka 2020. aastal ilmus Eesti Kirjandusmuuseumi Teaduskirjastuses väljaanne "Euroopa, esteedid ja elulähedus. Semperi ja Barbaruse kirjavahetus 19111940” (koostaja Paul Rummo, peatoimetaja Marin Laak). Samasugune väärtus on kogumist saatval ja kajastaval kirjavahetusel (nt Kikas 2017), suhtluskanalil, kust võib ootamatult leida olulisi märkusi ning tänapäeval niivõrd hinnatud metaandmeid.

\section{Kirjavahetuskogu olulisus uurimisainesena}

Käsikirjaliste arhiivimaterjalide hulka kuuluvad nii käsikirjad, välitööpäevikud, mälestusalbumid jm, kuid ka kirjavahetus, mille füüsiline paiknemine on ambivalentne - üks osa sellest on eraldi kirjavahetuskogus ning osa (kirjad, mis sisaldavad otseselt saadetise andmestikku või olid muul moel saadetise juures olulised) on leitavad käsikirjadesse köidetuna. Kirjad on üheks kommunikatsioonivõimaluseks (Korb 2013: 8; Stanley 2004: 202) ning rahvaluulekogumise varasematel perioodidel, sh valdavalt ka telefoni ja muude lähikontaktide puudusel, oli kirjavahetus omavahelises suhtluses asendamatu. Kirjavahetuse puhul võiks oletada, et seda on folklooriarhiivides tajutud ennekõike loomupärase suhtlusvahendina, andmete saamise ja kontaktivahendina, mitte tingimata eraldi uurimisainesena. Viimase olulisus tekib ja muutub aja jooksul. Arhiiviallikana on kiri fragmentaarne ja hajuv, kuid omab siiski n-ö sõnaõigust ja on vaadeldav osana elulookirjeldusest (Stanley 2004: 203-204; Annuk 2006a: 41, 45). Nõukogudeaegne rahvaluulekogujate kirjavahetus kajastab kaastööliste arvamusi nii enda kogutu kohta, kuid selles leidub ka tagasisidet või isegi sooviavaldusi näiteks toonaste Eesti Raadio rahvaluulesaadete osas. Samavõrra näitab kirjavahetus arhiivitöötajate ja korrespondentide vahelist suhtlust ja omavahelisi positsioone (nt Korb 2015: 19-21).

Kirjavahetuses edastasid osakonna töötajad peamiselt juhendeid ja tagasisidet kaastöölistele materjalikogumiseks, kutseid seminaridele, õnnitlusi jne. Muuhulgas jagasid töötajad oma kirjades tihtipeale kogumisretkede rännakumuljeid ja vabandasid, kui polnud lubatult kellegi juurde jõudnud ning põhjendati ka, miks nii läks - tehnilised probleemid, sõit, ajapuudus jne. Samuti on kirjavahetuskogus kirju, kus kajastub rahvameditsiini kogumise taust ja ettetulevad küsimused või raskused - näiteks on kaastööline Liina Voormann kurtnud, kui raske on kätte saada arstisõnu ning Ottilie Kõiva on Voormannilt 
uurinud, kas Voormanni osutatud arstisõnade raamatu valdaja oleks nõus eset tasu eest loovutama või ajutiselt laenama.

Kaastöölised omakorda jagasid teavet võimalike ja olemasolevate kogujate või pärimuse kandjate kohta, kelle tervis oli juba vilets ning vanus kõrge. Kirjutati ka isiklikumat infot enda pere, laste, ning paljudel juhtudel tervise kohta. Ilmselt võimaldasid ajapikku tekkinud soojemad suhted folkloristidega avameelsust isiklikku sfääri puudutavate küsimuste jagamisel. See ei tähenda muidugi, et sõbralikum suhtlus oleks tekkinud kõigi kaastöölistega, kuid oli palju neid, kellega suhtlus muutus mitteametlikumaks ja viimaks isiklikukski. Kirjasaatjatega parasjagu tegeleva folkloristi (see amet vahetus töötajate vahel, kuid kaastööliste kirjavahetus ei olnud tingimata kinnistunud just parasjagu korrespondentidega tegelevale töötajale) ja usinamate või pikaaegsemate kaastööliste vahel tekkis omamoodi sümbioos, n-ö laiendatud pere, kus vastastikku headele ja halbadele aegadele kaasa elati. See ei olnud ainult pelk viisakas vormelikasutus, vaid ka siirus ja heatahtlikkus.

Folkloristide kui ametiasutuse esindajate positsiooni kaastööliste vaates võiks siin kõrvutada ehk isegi psühholoogi, aga kindlasti kaastundliku sõbra omaga, kes kuulab mured ära ning keda saab usaldada. Järgmistes kirjades vastu kõlavad lohutus- ning kiidusõnad kaastöölistele tõid kindlasti meelerahu ja tõstsid enesehinnangut. Usaldust asutuse vastu näitab veel tõik, et kirjandusmuuseumi rahvaluule osakonnalt paluti nii mõnigi kord abi lisapensioni või muu toetuse saamisel ning need palved võimalusel täideti.

\section{Tervisekirjeldused kirjavahetustes}

Kirjade kui isiklike tekstide vabam vorm (Annuk 2004: 56) võrreldes nt ametlike dokumentidega ja pikemaajalised suhted muuseumitöötajatega lubasid tõenäolisemalt avameelsust kirjavahetuses. Nii on terviseteemad ja haigustest kirjutamine ühe kirjavahetuse puhul nagu väikesed, episoodilised haigusnarratiivid (Kleinmann 1988), kujundades ja kirjeldades ühe kogumistöö kulgu ja tulemusi. Uurides üht või teist konkreetset kirjavahetust on näha, kuidas tervisest kirjutamine muutub omamoodi lõimeks, mis seob erinevad kirjad erinevatest aastaaegadest ja aastatest, andes isiklikuma konteksti rahvaluulematerjalide kogumisse. Allpool on selline lõim näha Mary Kaasiku ja Gustav Kallasto kirjavahetuses.

Üldistatult võib öelda, et tervis on kaastööliste kirjades valdavalt üsna esimesel kohal. Tervise mainimine, tervise järele pärimine on vaadeldav retoorilise võttena (vrd Stanley 2004: 217; Annuk 2006a: 43), millega alustada või jätkata kirjavahetust. Peamiselt kirjutati tervisest juhul, kui üksteist vastastikku 
paremini tunti ja oli tekkinud tihedam suhtlus, kuid avameelsus terviseprobleemides tähendas ka selgitust ja vabandusi, miks ei oldud lubatud või soovitud töödega niikaugele jõutud kui algselt plaaniti, miks ei ole võimalik erinevatele sündmustele kohale sõita või ka katkendliku kirjavahetuse pärast.

Teinekord edastasid kaastöölised teateid oma (tervislikest) probleemidest üsna üksikasjaliselt. Nii kurdeti kirjades, et bussijaam on kaugel, arsti juurde ei pääse või et pole võimalik tulla loodetud lindistamisele, kirjeldati, millist ravi tervisehädade puhul parajasti saadakse (siinjuures on nii mõnigi kord lisatud põhjalik ravi kirjeldus ja areng) ning rahvalaulikute puhul võis külmetushaigus olla viinud hääle. Mõningates kirjavahetustes võtab oma tervislikust seisundist ülevaate andmine suisa pool kirjast, teine pool jäi tehtud ja saadetud kogumistööst ülevaate andmisele. Kaastööliste tervise järele pärisid folkloristid ka ise - enamik vabatahtlikest abilistest oli ju siiski pigem kõrgemas eas, vahel ka liikumisraskustega ning elasid kaugemates maakohtades. Nii on kirjavahetuskogus säilinud ärakirjades kaastöölisi manitsetud oma tervise eest hoolitsema ja arstide nõuandeid kuulama.

Kirjades avaneva terviseteema uurimine toob muidugi omakorda kaasa eetilisi probleeme. Eve Annuk on küsinud, kuivõrd eetiline on kirjutamine inimesest, kes on juba surnud ja ennast seetõttu kaitsta ei saa, ning milline õigustus võib olla (era)kirjade kasutamisele uurimustöödes (Annuk 2006a: 37-38; Annuk 2006b). Rahvaluule osakonnale laekunud kirjavahetus ei ole otseselt kategoriseeritav erakirjavahetusena - kirjandusmuuseum oli ametiasutus ja kaastöölised olid sellest hästi teadlikud. Samuti pole kirjavahetustele sätestatud kasutuspiiranguid ning andmeid kirjavahetusest on rakendatud mitmete uurimuste teenistusse. Sellegipoolest on kirjades avanevat pilti vaadates uurija ees küsimus, kust hakkavad jooksma eetilised piirid, eriti juhul, kui kirjades kajastub nt kodune vägivald. Vaevalt mõlkus osakonna töötajatelgi peas teadmine, et ühel hetkel on nende kaastöölistele suunatud kirjades kirjutatu uurimisaineseks. Uurija seisukohast on üllatavgi, kuivõrd avatult jagati oma tervise- või muid isiklikke muresid ja hirme. Käesoleva uurimuse taga on peamiselt küsimus, kuivõrd olid rahvameditsiinilise materjali kogujad ise altid oma tervisest rääkima ning kas ja kuidas kommenteeriti tervist ja teadmisi ravimisest rahvameditsiinilistes üleskirjutustes. Kuna siin artiklis kõlav kogujapoolne hääl on kaastööliste puhul isikustatud ning terviseteema jääb siiski üldisematesse piiridesse, olen uurijana teinud valiku jätta anonümiseerimata ka arhiivitöötajate nimed (vrd Korb 2013: 13). 


\section{Rahvameditsiini kogumiskava 20. sajandi keskel}

Nõukogude perioodi folkloristikas valitsesid folkloorikogumises uued arusaamad ning usund jäi nendest eelistustest välja (Tupits 2009: 74; vt ka Oras 2008: 60-74). Vähemalt Eesti folkloristid täielikult usunditeemat siiski ei ignoreerinud ning 1960. aastatel tehti selgeid samme rahvausunditeemade uurimiseks ja taasesiletõstmiseks ning kasutati ära ka võimude poolt pakutud õlekõrsi oma valikute põhjendamiseks (Goršič 2018: 135-137). Suunatumalt hakati eesti rahvameditsiini uurima siiski alles 1970. aastatel (Tupits 2009: 73), kuid see ei tähendanud nagu oleks kogumistöö sinnamaani unarusse jäänud. Rahvameditsiini ehk otseselt terviseteemalist folkloori koguti rahvaluule osakonna kontekstis ekspeditsioonidel ja kaastöölistelt ning jõudumööda korraldati usundialaseid kogusid (Tupits 2009: 75-81).

1950. aastate teisel poolel said omavahel kokku kaks meditsiinidoktorit, kelle initsiatiivil algas suurem rahvameditsiinikogumine. Nendeks olid Tartu Riikliku Ülikooli neuroloogia ja sisehaiguste propedeutika kateedri assistendina töötanud Kaljo Villako ja 1958. aastast hügieeni kateedri juhatajana töötanud Mihkel Kask. Küsitluskava pandi kokku koostöös kirjandusmuuseumi folkloristide Herbert Tampere ja Erna Normanniga ning avaldati 1959. aastal Nõukogude Eesti Tervishoius (Kask \& Villako 1959). Lisaks saadeti kava arhiivi kaastöölistele.

Koostatud küsimustik on üks suurimaid ja põhjalikemaid eesti rahvameditsiini käsitlevaid küsitluskavasid 20. sajandi jooksul, ehkki oli suunatud pigem meedikutele kui tavakogujatele, sest Kase ja Villako arvates said meedikud oma teadmiste tõttu materjalist paremini aru. Mõlema meditsiinidoktori arvates olid selleks hetkeks olemasolevad andmed rahvameditsiinist puudulikud ja osalt väheväärtuslikud. Puudujääkide põhjusteks oli nende hinnangul ennekõike meditsiinitöötajate ükskõikne suhtumine nii rahvameditsiini kui ka meditsiiniajaloosse. Kogumismetoodika tuli siiski laenata folkloristidelt ja etnograafidelt, kellel oli erialane väljaõpe ja praktilised kogemused.

Küsitluskava koosnes kolmeteistkümnest teemast: üldküsimused, sisehaigused, kirurgilised haigused, nakkushaigused, silmahaigused, kõrva-nina-kurguhaigused, hambahaigused, vaimu- ja närvihaigused, lastehaigused, rasedus- ja sünnituskombestik, naistehaigused, nahahaigused ning inimese- ja elamusöödikud. Erinevate teemapunktide all oli välja toodud üsna palju rahvapäraseid nimetusi, mis ühest küljest olid nähtavasti mõeldud arstidele küsitlemisel abiks informantidega ühise keele leidmiseks, kuid teisalt aitasid ka n-ö tavainimestel lihtsamini küsitluskavaga suhestuda. 
Valdav osa vastustest laekus korrespondentide kaudu, kellest enamikul vaevalt meditsiinilist haridust oli. Meedikutest koduloohuvilised Ilse ja Lemming Rootsmäe kogusid vihikutäie kirjeldusi rahvameditsiini kohta, olles seega ühed vähestest arstidest, kes järgisid kolleegide üleskutset ${ }^{2}$ (Lätt 1968: 78-80).

1960. aastate kogumisaruanded näitavad, et küsitluskava mõjul saadeti rahvaluule osakonnale märkimisväärne hulk rahvameditsiini sisaldavaid vastuseid, neist mõned väga mahukad. Vähesel määral laekus materjale juba 1959. aastal, kuid kõige aktiivsemalt saadeti vastuseid vahetult küsitluskava avaldamisele järgnenud aastatel. Eriti suur hulk vastuseid saabus 1960. aastal. Meedikutest Rootsmäedele lisaks kogus Muhus ja Saaremaal rahvameditsiini hügieenikateedri üliõpilane Eda Aer ${ }^{3}$ (Lätt 1962: 51-56; Tampere 1962: 60). Ka 1962. ja 1963. aasta materjalides oli ühiskondliku sisuga rahvaluule, muistendite ning vanasõnade kõrval tugevalt esil rahvameditsiin (Lätt 1965: 89-95). Kuna ülevaate kirjutanud folklorist Selma Lätt väljendas andmete rohkuse osas üllatust, võib oletada, et ilmselt ei oodatud nii püsivat populaarsust või teadmiste jagamist rahvameditsiini osas.

Üldregistrite põhjal tõuseb esile kindlate kogujate pidevalt saadetud rahvameditsiiniline andmestik. Oli neidki vastajaid, kes keskendusid püsivalt just Kase ja Villako küsitluskava täitmisele ja rahvameditsiini kogumisele. Registrites leiduvatest märkustest nähtub, et kaastööliste laiemalt ette võetud kogumiste puhul on aluseks olnud mainitud küsitluskava, seejuures ei ole alati vastatud kõigile kolmeteistkümnele punktile, vaid esindatud olid eeldatavalt informandi teadmistest lähtuvad teemad. Üksikute või väiksemamahuliste vastuste puhul võib tegu olla pigem juhusliku korjega, kuid küsitluskava mõju ei saa välistada. Registri sissekannete kohaselt koguti üsna palju nõidussõnu ning pärimust rahvaarstide kohta. Ka rahvabotaanikast leidub arvestatavalt vastuseid, oluliselt vähem on rahvaveterinaarset pärimust. Mõnevõrra talletati pajatusi kohalikest arstidest või ämmaemandatest.

Aktiivseimad rahvameditsiini kogujad olid Marta Mäesalu, Endel Mets, Mary Kaasik, Emilie Poom, Mihkel Priimets, Linda Palu, Johannes Palm, Ervine Kasemets, vanematest saatjatest veel Olga Hildebrand. Mitmed vastuste saatjad olid juba arhiivi kauased ja aktiivsed kaastöölised. Samaaegselt kogusid korralistel välitöödel rahvameditsiini ka folkloristid, eriti Mall Proodel (Hiiemäe), mõnevõrra Selma Lätt, Erna Tampere, Arvo Krikmann, Lilia Briedis rahvaluule osakonnast; samuti Udo Mägi, Ülo Tedre, Richard Viidalepp ja Pille Kippar toonasest Keele ja Kirjanduse Instituudi rahvaluulesektorist.

Ehkki vastuste saabumise kõrgaeg jäi 1960. aastate algusse, vähenes rahvameditsiini sisaldavate andmete aktiivne laekumine alles 1970. aastate keskpaigaks. Küsitluskava palusid kaastöölised kirjavahetuse järgi endale 
kogumisabiks ka 1980. aastatel. Tuleb siiski märkida, et rahvameditsiini kohta kogutud andmemaht jäi alla nt rahvalaulude, rahvajuttude ja lühivormide mahule (Tupits 2009: 81-95).

Kase ja Villako algatatud üleskutse kohta märkis etnoloog Ants Viires mituteist aastat hiljem, et kogumise tulemustest pole midagi kuulda (Viires 1975). Alljärgnev on siiski väike sissevaade kahe kaastöölise kogutule ning ka nende endi tervise ja heaolu teekonnale kirjade kaudu.

\section{Kogujatetandem Virumaalt: Mary Kaasik ja Gustav Kallasto}

Virumaalt Kiviõlist tegid nõukogude ajal rahvaluule osakonnale kaastööd muuhulgas Mary Kaasik ja Gustav Kallasto. Teised sel ajal aktiivselt tegutsevad Virumaa kaastöölised olid nt Armilda Hallik (Iisaku khk), Ella Kaljuvee (Haljala khk), Salme Kiislar (Jõhvi khk), Hugo Lepiku (Viru-Jaagupi, Rakvere khk), Eduard Leppik (Väike-Maarja, Simuna khk), Helene Liivak (Lüganuse khk), Endel Mets (Jõhvi khk), Linda Palu (Haljala, Rakvere khk), Selma Vasar (Viru-Nigula khk), Villem Viirmann (Simuna khk).

Mary [Meery, Meeri] Kaasik (Rekkor) (1907-1977) oli pärit Maidla vallast Unikülast, õppis Narvas õmbluskoolis õmblejaks ning töötas rätsepana omal käel nii linnas kui maal. Lisaks kirjutas ta külarahva eest ametiasutustesse ning töötas mitmel muul töökohal. Samuti kirjutas ta ise laule ja luuletusi. Gustav Kallasto (1894-1979) sündis Erra vallas Kaunurme külas, töötas tallipoisina ja õppis lukksepaks, pärast Esimest maailmasõda töötas kuni 1957. aastani raudteel (RKM II 257, 209/12).

Rahvaluulekogumise algusaegadest on Mary Kaasik oma eluloos kirjutanud, et ta oli 1957. ja 1958. aastal mitu kuud haiglas ning pärast seda väga masendunud oma tervislikust seisukorrast. Lugenud 1961. aastal ajalehest teadet rahvaluule kogumise võistlusest, kirjutas Mary Kaasik Tartusse kirjandusmuuseumisse, sai sealt juhendid ning asus innuga koguma. See tegevus peletas mõtted haigusest ning ta leidis Gustav Kallastos kaastöölise ja abilise. Olles algselt kogenud mõne pereliikme märkuseid rahvaluulekogumise kohta, tuli ta 1962. aastal võistluse lõppedes tagasi teise koha ja 50rublase preemiaga, pärast seda ei küsitud temalt ta enda sõnul enam, miks ta sellise asjaga tegeleb. Alates 1962. aastast koguski Mary Kaasik püsivalt koos Gustav Kallastoga rahvaluulet (RKM II 257, 213/16) ning nende peamine kogumispiirkond oli Virumaa. 


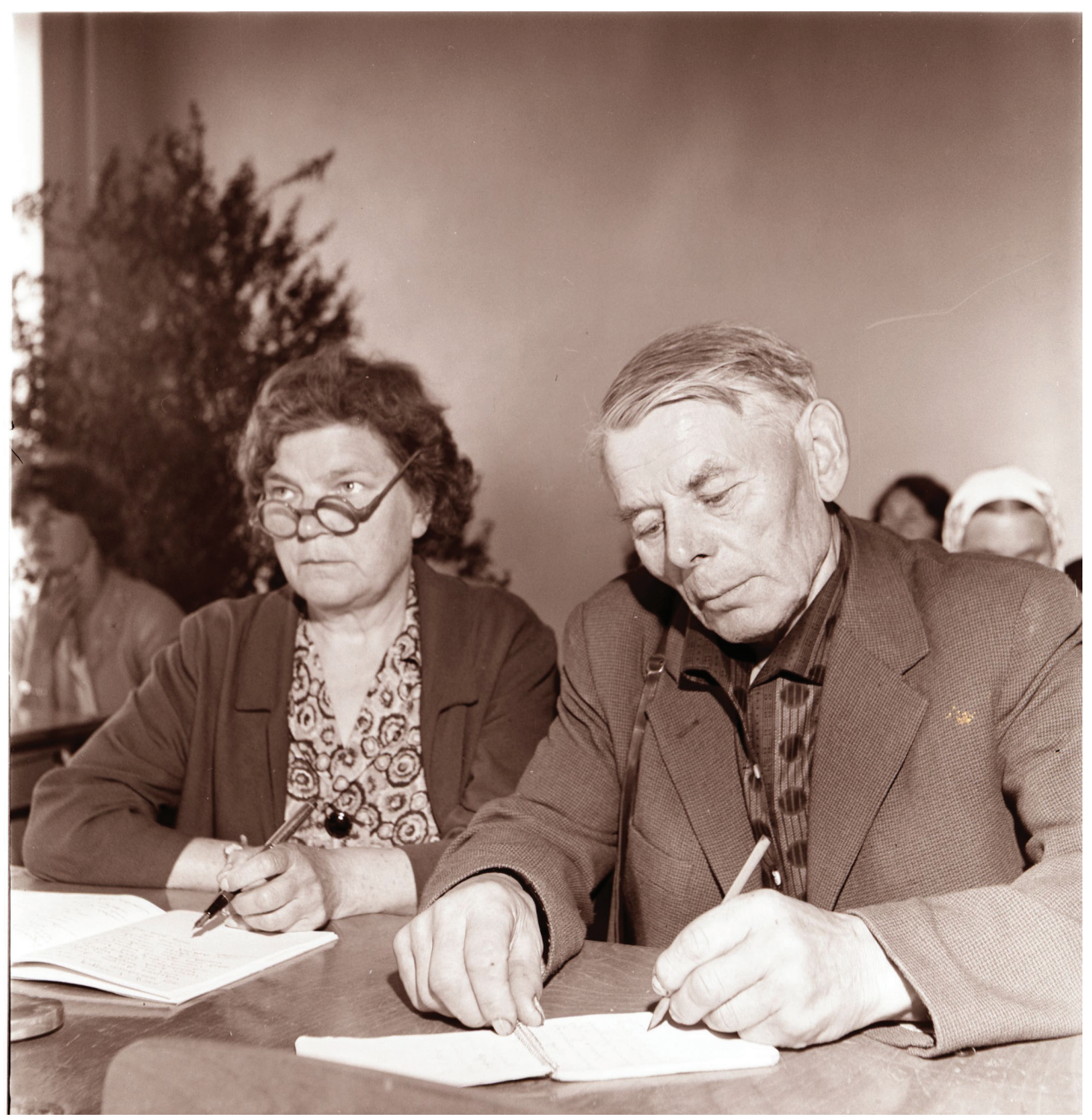

Foto 1. Rahvaluule osakonna töötajate ja korrespondentide kokkutulek Kadrinas 26. ja 27. juunil 1965. Korrespondendid Mary Kaasik ja Gustav Kallasto Kiviõlist. R. Hanseni foto 1965. ERA, foto 7411 .

1961. aastal korraldas rahvaluulearhiiv kogumisvõistluse "Ajaloolisi sündmusi ja ühiskondlikke vahekordi kajastavad laulud”, mis lõppes märtsis 1962. Tegu oli populaarse võistlusega, mille tulemusel koguti üle 5000 laulu (11 000 lk) ning sellest võttis osa üle 80 inimese. Lugudele lisaks koguti ka muid folklooritekste. Mary Kaasik jagas võistlusel nelja kaastöölisega teist kohta. Võistluse ülevaates märkis Ingrid Rüütel, et Mary Kaasik kirjutas laule paljudelt isikutelt, lisades sealjuures täpse andmestiku (Rüütel 1962: 63-70). Siinkohal tasub märkida, et Kaasik ja Kallasto võitsid preemiaid teistelgi kogumisvõistlustel. 
Kaasik ja Kallasto kogusid ühistel kaastööaastatel hulgaliselt laule, lühivorme, jutte, mänge, rahvausundit, kombestikku, kalendripärimust, lastepärimust, ajaloolist ja kohapärimuslikku materjali, sh jagasid nad ka oma sõjamälestusi, Gustav Kallastolt on näiteks rindemälestusi Esimesest maailmasõjast (RKM II 222, 515/32). Kokku kogusid nad üle 3300 lehekülje pärimuslikku materjali ning kaheksa fotot, sh kaks nende portreed. Kaasik ja Kallasto on järginud rahvaluule osakonna küsitluskavu. Neile, nagu teistelegi kaastöölistele, saadeti toonase kogumisjuhendi Rahvapärimuste Koguja (1961-1976) numbreid. Nii on käsikirjast käsikirja kogutud materjali kese kindlatel alateemadel ning aastatepikkuse kaastöö jooksul hakkasid küsitletavad teemad loomuldasa ka korduma.

Ei ole selge, kui palju mõjutasid Mary Kaasiku ja Gustav Kallasto kaastöö algust näiteks Keele ja Kirjanduse Instituudi folkloristide ekspeditsioonid IdaVirumaale 1958.-1960. aastatel. Samuti ei ole selge, palju avaldasid mõju need kaastöölised, kes piirkonnas juba ringi käisid ja kogusid, neist üks nimekamaid nt August Martin, kes alustas kaastööd kirjandusmuuseumile juba 1957. aastal (Goršič 2017).

Üks esimesi kirju EFAM, RO kirjavahetuskogus, millest on näha Mary Kaasiku kontakt kirjandusmuuseumiga, on veebruarist 1962, mil ta saatis 1961. aastal kogutud revolutsioonilisi ja mõisalaule eelpool viidatud võistlusele. Kirjas Ingrid Rüütlile mainib Mary Kaasik, et soovib tehtud tööle tagasisidet, siis tean edasi töötada. Lisaks täpsustab ta, et ta õige nimi on Meeri, kuid kirjutatakse Mary. Kirjale kirjutas ta ise alla kui Meery (RKM II 118, 9/10). Ühtluse huvides on siin artiklis kasutatud nimekuju Mary, v.a juhtudel, kus originaalis on kirjas muu nimekuju. Tema esimeseks informandiks oli kirjale järgnenud materjali ja Kaasiku kirja kohaselt Gustav Kallasto (EFAM, RO). Reaalselt tegelesid rahvaluule kirjapanemisega mõlemad, ehkki n-ö puhas materjal on peamiselt Mary Kaasiku käekirjaga.

Kirjavahetuskogus on 33 Kaasiku ja Kallasto kirja, 22 ärakirja rahvaluule osakonna töötajatelt ning hulgaliselt aastate jooksul osakonnale saadetud tähtpäevapostkaarte. Kirjade põhjal võib järeldada, et folkloristidega oldi viisakates, kuid südamlikes suhetes - enamik vastastikku adresseeritud kirju algab sõnaga "Armas", millele järgnes kas konkreetne isikunimi või näiteks Mary Kaasiku poolt ka "rahvaluule pere". Vaid vähestel kordadel algavad kirjad ametlikumalt ("Lugupeetud"). Kaasiku ja Kallasto kirjapartneriteks rahvaluule osakonna poolelt olid 1960. aastate esimesel poolel Selma Lätt ja Ingrid Rüütel, 1960. aastate teisel poolel Ellen Liiv ja Ingrid Rüütel, aga ka Mall Hiiemäe (Proodel), 1970. aastatel nii Ottilie Kõiva, Ingrid Rüütel kui ka Mall Hiiemäe ning viimaks peamiselt Kristi Salve. 


\section{Rahvaluule osakonna juhendustöö}

Korrespondendikaartidelt on näha, et Mary Kaasiku ja Gustav Kallasto kaastöid hinnati valdavalt heaks või ka väga heaks, üksikute saadetiste puhul on hinnang olnud "rahuldav" või "osalt hea" või tekkis küsitavusi materjali autentsuse osas. Viimasel juhul eraldati see osa kirjavahetuskogusse. Sellest anti kaastöölistele ka teada.

Kaastööaastate jooksul märkasid Kaasik ja Kallasto muudki materjali, mida inimesed rääkisid, ja küsisid seetõttu nõu, mida tuleks üles kirjutada. Üks selline järelepärimine saabus Mary Kaasikult 1968. aastal kirikuajalooliste lugude kohta. Sellele on Ingrid Rüütel vastanud, et tegu ei ole otseselt folkloristide töömaile kuuluva teemaga, kuid väga huvitava materjali korral võib selle kirja panna (RKM II 257, 231; EFAM, RO).

Novembris 1970 küsis Mary Kaasik juhendust, mida teha Esimese maailmasõja materjalidega, mis on aastatel 1938-1939 ühe õpilase poolt kaustikusse kirjutatud. Sellele vastas taas Ingrid Rüütel:

[---] Ilmasõja materjal meie fondidesse ei kuulu, iseasi, kui seal oleks rahvapärimuslikku materjali. [---] (EFAM, RO)

Üheks põgusaks teemaks on kirjavahetuses olnud ka materjalide vormistamine. Nii näiteks on novembris 1971 lisanud Ottilie Kõiva täpsustusi vormistuse kohta:

[---] Üldiselt on kõik korras ja andmeid küllaldaselt, ainult esimeses vihikus pole päris selge, millised mälestussalmid kelleltki on kirjutatud, sest andmed on ühe numbri all. Ehk saate mustandi järgi neid andmeid veel täpsustada. Vihiku algul on Teil teatmete päritolu märgitud lehekülgede järgi. Oigem on märkida teatmete järjekorranumbrite järgi, sest vihikud köidetakse siin kokku ja leheküljenumbrid muutuvad. Parem oleks vihikute lehekülgi mitte nummerdada, või kui, siis pliiatsiga, et saaks hiljem kustutada. [---] (EFAM, RO)

Arhiivimaterjalide kohaselt nummerdasid Mary Kaasik ja Gustav Kallasto siiski oma saadetiste lehekülgi omamoodi, hiljem on numeratsioon arhiivis maha tõmmatud ning vastavalt ümber pagineeritud. Lisaks on arhiivitöötajate poolt tehtud osutusi andmete täpsuse ja leviku kohta. Nt juulis 1971 kirjutas Mall Hiiemäe kogutu kohta:

[---] Üldiselt on andmeid piisavalt, aga teinekord juhtub, et võiks midagi huvitavat lisada leviku või esitamisviisi vm. kohta, siis lisage julgesti. [---] (EFAM, RO) 
Taustaandmete väärtuslikkust on Mall Hiiemäe rõhutanud ka 1972. aasta septembris:

[---] Aitäh saadetud laulude eest. Tänu selgitustele nende kasutamise kohta tõuseb nende väärtus tavalisest lauluklade väärtusest tunduvalt üle. [---] (EFAM, RO)

Mary Kaasikut ja Gustav Kallastot juhendati kirjades ka laulukladede ümberkirjutamise juures ning küsiti vajadusel täiendavaid andmeid laulude ja lauliku kohta.

Üheks teemaks, mis kogumistöö juhendamise alal jõuab kirjadesse mitmel korral, on mitterahvaehtsad jutud. Nii on detsembris 1974 kirjutanud Kristi Salve manitsuse, et ülipopulaarsetesse ja trükis avaldatud juttudesse tuleb suhtuda ettevaatusega ning jutustajat tuleb hoolikalt küsitleda, et teada saada, kust jutt pärit on. 1976. aasta jaanuaris hoiatas Kristi Salve Mary Kaasikut taas juttude eest, mis on rahva seas üliharuldased ning võivad olla õpitud raamatuist:

[---] Ka edaspidi palume olla hoolsamad materjali kontrollimisega, see tähendab, kirjutada tuleb ainult seda, mida jutustajad teavad, kuid mitte kõike seda, mida nad teavad. [---] Teil on varemgi raamatust pärinevat sisse lipsanud (naljandeid näiteks). [---] (EFAM, RO)

Mary Kaasiku vastusest selgub veebruaris 1976, et on konkreetselt jutustajalt üles kirjutanud selle, mis too on õppinud oma emalt ja mida ise mäletab:

[---] Kirja panen need jutud mis inimene teab, mitte raamatust. Seda ma tean, mis on vajalik kirja panna. [---] (EFAM, RO)

Samuti lisas ta kirjas täpsustusi muude varasemate küsimuste kohta ning jagas infot jutustaja kohta, kelle juures ise parasjagu viibis. Ühtlasi juhendas ta folkloriste, kuidas nende juurde koguma jõuda. Sellele vastas Kristi Salve peagi, lootes võimalusel kõnesolevat jutustajat külastada ja salvestada. Hilisemast kirjavahetusest selgub, et kavatsetud lindistamisreis jäi siiski ära, kuid Mary Kaasiku vahendatuna muuseumisse saadetud lauluklade hinnati väärtuslikuks.

\section{Rahvameditsiinilise materjali kogumine}

Üheks algusaastate kogumisteemaks Kaasikule ja Kallastole oli rahvameditsiin. Vastavat materjali laekus neilt aastatel 1962-1964 ning 1966, kokku üle kahesaja lehekülje. Huvi teema vastu näitas üles Mary Kaasik ise ning kogutud 
materjali põhjal võib arvata, et ta enda teadmised antud teemast ja isiklikud terviseprobleemid innustasid koguma. Nii kirjutas 1962. aastal Mary Kaasik kirjas Ingrid Rüütlile muuhulgas:

[---] Olen huvitatud vana aegsetest arstiteadusest palun juhendid. [---] (EFAM, RO)

1962. aasta detsembris adresseerisid Kaasik ja Kallasto oma kirja Herbert Tamperele ning palusid edasi anda kaks vihikut kogutud rahvameditsiini teadetega, ehkki olid kaotanud küsitluskava ning nad polnud kindlad, kas materjal vastab nõuetele (RKM II 146, 179). Esimeses saadetises, kahes vihikukeses, on kirjas lastehaigused, hammustused, vigastused, külmetushaigused, liigesehaigused, putukatõrje, samuti jutud kohalikest ravitsejatest (RKM II 146, 365/412). Osa kogutud materjalidest pärineb kogujailt endilt.

Järgmine materjal veidi rohkemate rahvameditsiini andmetega saabus 1963. aasta lõpul. Mary Kaasiku saatekirjast aimub ka vihje tema enda tervise kohta:

\section{Sm S Lätt}

Saadame oma kogutud töö ära. Kahjuks pildid jäävad saatmata, seda teeme hiljem.

Kaks pilti lisasime juurde. Käesoleva aasta töö on tehtud. Järgmine aasta algame uue hooga, kui tervis lubab. Soovime Teile head käes oleva aasta lõpu.

Teid kõiki tervitades

$M$ Kaasik ja Kallasto

11 XII 1962 Kiviõlis (RKM II 162, 9)

Kaasiku ja Kallasto kogutud rahvameditsiini materjali hinnates võib öelda, et peamiselt koguti Kase ja Villako küsitluskava järgi ning vastused on temaatiliselt pealkirjastatud, nagu nad olid ka küsitluskavas. Toonase põhimõtte järgi ei soovitatud kogujatel lisada omapoolseid kommentaare ja hinnanguid folkloorimaterjalile. Mary Kaasik tegi siiski rahvameditsiinipaladesse mõningaid märkusi, mis viitasid ta enda kogetule ning kasutatavale. Nii märkis Mary Kaasik juba esimese saadetise algul, kust on pärit tema teadmised:

Meil oli kodus 8 last ema ja isa ravisid kõik haigused ise kunsti ja maarohtudega. Sellepärast on minul kõik meeles kuidas ema ravis. (RKM II 146, 398 (1) < Lüganuse khk, Kiviõli - Mary Kaasik < Mary Kaasik, snd 1907. a (1962)) 
Mary Kaasiku enda teadmised rahvameditsiinist on katnud väga mitmeid küsitluskava teemasid, allpool on toodud mõned näited üleskirjutatud ravivõtetest, sh need, mida tarvitati kodus:

Laste haigused. Kärnad peas. Kui lapsel pea sügeles ja täid olid peas. Kõige pealt aeti juuksed maha. Siis pesti, keedeti kar-koorega, selle kartuli keemise veega pesti pea korrati mitu korda. (RKM II 146, 398 (I) < Lüganuse khk, Kiviõli - Mary Kaasik < Mary Kaasik, snd 1907. a (1962))

Kahelpoolsed. Kui kurk oli valus neelata ei saanud. Ravi. Pandi kuuma tuhka sukasääre sisse ja seoti ööseks ümber kaela, ehk peeti nii kaua kui tuhk oli täesti ära jahtunud. Hommikul kui magamast ärkasid pidid pesemata sõrmed kurku ajama ja vajutama kahelpoolseid nii et öökima ajas. Kui rinnad kridisesid siis määriti kanarasvaga tilgutati tärpentiini padja peale. Siis veel kuristati soolaveega vesi oli leige. (RKM II 146, 401 (4) < Lüganuse khk, Kiviõli - Mary Kaasik < Mary Kaasik, snd 1907. a (1962))

Nohu. Nohu tekis külmetuse tagajärjel. Raviks nuusutati ninna nuuskpiiritust. Siis põletati vana linast riiet seda nuusutati. Nuuskpiiritust nuusutatakse tänapäev. Haige hoiti hästi soojas. (RKM II 146, 404 (7) < Lüganuse khk, Kiviõli - Mary Kaasik < Mary Kaasik, snd 1907. a (1962))

Paised. Paised oli kahte seltsi vere ja mäda paised. Alul kui paise hakkas veidi sügeles hiljem mädapaisele aias mädapää, või vistriku otsa, kuid vesi paise oli suur punane muna kui vanaks sai läks siniseks. Paised olid väga valusad. Paised pidid tekkima pahast verest. Ei olnud nakavad. Paiseid põdeva inimesega vihtlesid ühes saunas, teisele isikule ei hakkanud külge. Ma olin 16-18 a. vana kannatasin paisete pärast. Ükskord paise hakkas oli väike mädapea otsas panin joodi peale vistrik kadus, kuid umbes paar nädalat käevarre liha tegi koledat valu et magada ei saanud. Ühel pühapäeva lõi augu lahti puhast verd ja mäda jooksis nii kaua kui haav oli puhas. S.O. 1923-1925 a. Paiseid raviti. Kui hakkas juba täiskasvanuks saama. Pandi peale küpsetatud sibul, soola leiva puru, sulatatud pigi paberiga, soolane pekiliha lõik ja keedetud linaseemne mähis. Nimetatud ained pandi paisele peale ja seoti vana puhta linase riidega kinni valgega mitte värvilisega. Vahes isa võttis terava habemenoa ja lõikas paise keskelt risti nii et neljaks mäda jooksis välja haav paranes peale pandi veel küpsetatud sibula tükk ja seoti kinni kuni paranemiseni. Vahest jättis väikse armi järgi. Käesoleval ajal ei ole paiseid ega ka ühtegi armi. (RKM II 146, 405/7 (9) < Lüganuse khk, Kiviõli - Mary Kaasik $<$ Mary Kaasik, snd 1907. a (1962)) 
Langetõbi. Langetõbe tunti inimene kukus maha ajas silmad punni verine vahupull tuli suu peale. Käed ja jalad keskused krampi. Üks naine tapas siili võtas siili verd, viis kodu pani musta kohvi sisse ja andis mehele sisse. Seda pidi nii tegema et haige ei teadand. Ma ei tea kas see rohi aitas. (RKM II 162, 102 (4) < Lüganuse khk, Kiviõli - Mary Kaasik < Mary Kaasik, snd 1907. a (1963))

Naiste haigused. Valud all kõhus, või munasarjades. Seda haigust raviti kuumaks tehtud kaertega. Kaerad kuumutati katlas kuumaks, siis pandi kotti sisse, kott pandi kõhu peale nii soojalt kui kannatas. Ka paiselehed kuumutati veega ja asetati mähisena kõhule. (RKM II 162, 103 (5) < Lüganuse khk, Kiviõli - Mary Kaasik < Mary Kaasik, snd 1907. a (1963))

Vaimuhaigused. Vaimuhaiguste põhjuseks on ehmatused, rasked hingelised üleelamised ja kannatused. Vaimuhaigeid rahvas kohtles kaastundlikult, vahest ka naerdi. Vaimuhaiget öoli: "Lollakas loll”. Vaimuhaige kannab isesugust riietust, armastab kanda lipsusi ja topsi oma riiete küljes. Nad ihaldavad suuremast seisusest ja paremast töökohast meest naist ja paremat töökohta. Vaimuhaige näeb olemata asju. Mõnes kohas on ta väljendused liiga targad, teises kohas räägib nii et paneb naerma. Rumala ja nõrgamõistusliku vahel on see vahe. Rumal lõhub, märatseb, teeb rumalusi, millest ta ise ei tea ega aru ei saa, ega oma tegude eest ei vastuta. Nõrgamõistusline naerab iseeneses, räägib segast juttu, nutab palju ei saa pisaraid tagasi hoida. Ka ei saa oma saladusi varjata. (RKM II 162, 206/7 (1) < Lüganuse khk, Kiviõli - Mary Kaasik < Mary Kaasik, snd 1907. a (1963))

Kirp. Kirp tekib mustusest, tolmust. Lakka tolmust, siis heinad on täis. Vanasti pesti toa põrandat kuuma veega, sellega hävitati. Käesoleval ajal TDD pulbriga ja vedelikuga.

Kirp aknast välja

Nahkpüksid jalga

(RKM II 162, 218 (10) < Lüganuse khk, Kiviõli - Mary Kaasik < Mary Kaasik, snd 1907. a (1963))

Jooksva rohi. Ise valmistasin kellegi õpetuse järgi 1958. aasta andsin teisele veel edasi. iga ainet oma äranägemise järgi I petrolium II Pensiin, III tärpetiin IV jood V sipelga piiritus VI sinep VII tinatur, VII ekspeller ja kapsin. Haige koht määrida ja soojalt kinni siduda. Kui nahk punetama hakkas maarisin vaseliiniga. Sellest ajast peale ei ole enam käsi haige. (RKM II 162, 219/20 (12) < Lüganuse khk, Kiviõli - Mary Kaasik < Mary Kaasik, snd 1907. a (1963)) 
Ühel juhul on Mary Kaasik väga otseselt kirjutanud enda terviseprobleemist, mida ta puudutab ka oma eluloos, ning sidunud selle küsitluskava küsimusega:

Unenäod. Inimene kellel on närvid haiged, näeb palju und, vaevleb enne magama jäämist mõtetega. Seda põhjustab üle töötamine liig väsimus ehmatus hingelised üleelamised. Ka sel põhjusel tekkisid silmade ette kujud ja elavad olevused ja iseenestes kadusid. Viimati kui inimene uinub magama järjest tekivad unenäod. Mida rohkem inimene närveerib, seda rohkem näeb und. Siis näeb ta kõige hirmsamat und mille peale inimene härkab unest kas kukub vette keegi tapab. Isegi juhtub seda, kui silm läheb kinni ei magagi veel, kui silmade ette ilmuvad kujud, mis sealsamas kaovad oled üleval kardad. Seda juhust on mul endal kaks kord ette tulnud. Rasketel aegadel. Mille tagajärjel haigestusid südame närvid ja hiljem klapi rike. Närvihaige inimene ei tohi kunagi üksinda olla tal peab olema tegevus ja ajaviidet temaga peab vestlema ja aega viitma. Teda ei tohi vihastada teda peab trööstima meelitama ja tema meelejärele olla. Vanasti ei arvestatud unenägu mingisuguse närvilikkusega, vaid igal unenäol oli oma tähendus, ja lähemal ajal pidi see inimesel kätte tulema ja seletati kohe ära kas see unenägu tähendab head või halba ette. [---] (RKM II 162, 207/9 (1a) < Lüganuse khk, Kiviõli - Mary Kaasik < Mary Kaasik, snd 1907. a (1963))

Gustav Kallasto seevastu, tundub, jäi rahvameditsiinilise materjali osas pigem teadmiste vahendaja rolli, ei folklooripaladest ega metaandmetest ei selgu tema isiklik rahvameditsiinivõttestiku kasutamine. Samas on tal mitmeid häid jutte kohalikust rahvaarstist:

Puusa paigale panemine. Jaan Isküll elas Savala külas Maidla vallas Virumaal. Teda tunti luude ja liikme paigale panijana. Aa mõisa preili ratsutas hobusega ja kukkus maha ja vasak puusa luu läks paigast ära. Mõisnik saatis tallipoisi Iskülale järele. Jaan läks Aa mõisa. Ta viidi preili tuppa, kus haige viibis. Preili ehmatas, habemega talu meest nähes. Ta ei lasknud vanameest ligi. Isküll tuli ära, sai vaevalt teise tuppa kui herra ja proua palusid teda tagasi. Isküll läks tagasi, kuid preili keeldus jälle: "Et niisugune prostoi mees peab tema puusa katsuma." Isküll tuli ära ja ütles: "Las ta jääda elust ajast vigasest, ega minul häda ole." Kuid treppi pealt kutsuti veel tagasi: “Et nüüd preili laseb kõik teha, mis Isküll tahab.” Isküll läks tagasi ja preili lubas, luud paigale panna. Isküll ütles: "Mul tuli sääl põlve ramu tarvitada." Tal tuli põlve ramu tarvitada. Ta rohus põlvega puusaluu paigale. Oli hele kirjatus, ja väike klõps, puusaluu oligi paigal. Isküll võttis preili käest kinni ja ütles: “Tule kõnni põrandal.” Preili tuli 
põrandale ja kõndis kuid puus oli haige. Isküll määras viis päeva voodis lamamist. Ta käis vaatamas seni kui haige täielikult paranes. Mõisnikul oli hea meel, andis Isküllile sada rubla, seekord sada rubla oli suur raha. See oli 1912 a. Jaani enda jutustus Gustav Kallastole 1920 a Kabalas. (RKM II 162, 220/3 (1) < Lüganuse khk, Kiviõli - Mary Kaasik < Gustav Kallasto, snd 1894. a (1963))

Gustav Kallastolt pärineb ka mitu lugu allaneelatud loomadest ja nende väljaajamisest:

Hiir kõhus. See sündmus oli Erra mõisas lamba karjatsega. Lambakarjane sõi kaalika piirakat. Ta jäi päeval odrarõugu juure magama suu lahti. Hiir läks talle suhu, ta neelas alla. Õhtul läks koju rääkis peremehele: "Et tal on hirmus valu kõhus." Siis peremees andis saunanaisele lõngaoli vett. Teisel päeval välja käies, nägi et temal oli väljaheites hiir see tegigi talle kõhus valu. See oli 1908 a suvel. (RKM II 186, 117 (2) < Lüganuse khk, Kiviõli - Mary Kaasik < Gustav Kallasto, snd 1894. a (1964))

\section{Tervisliku seisundi kajastused kirjavahetuses}

Ehkki Kallasto ja Kaasik kogusid rahvameditsiinilist materjali muude teemadega võrreldes oluliselt vähem, jäi terviseteema - kas enda või lähikondsete oma - püsiva osana nende kirjadesse. Rahvaluulematerjali kogumine ja saatmine käis võidu nii Mary Kaasiku kui Gustav Kallasto ja nende pereliikmete terviseprobleemide või surmadega ning need sündmused kajastuvad peaaegu kõikides kaaskirjades.

Nii näiteks jagas Mary Kaasik oktoobris 1967 folkloristidega oma muret õe haigestumise pärast (RKM II 222, 293). Seejärel sattus löögi alla tema enda tervis - 1968. aasta detsembris kirjutas Mary Kaasik:

[---] Wabandage tööd on vähe saata kogutud on, kuid minu haigestuse tõttu jääb osa saatmata. Wiibin haiglas sise osak südamega. [---] (EFAM, RO)

3. jaanuaril 1969 kirjutas Ingrid Rüütel vastu:

[---] Loodame, et Meeri Kaasik on juba terve ja sai pühad juba ilusasti kodus vastu võtta. Soovime teile mõlemale alanud aastaks tugevat tervist ja üldse kõike head! [---] (EFAM, RO)

Seejärel on kirjavahetuskogus paus kuni maini 1969, mil Mary Kaasik saatis töötajatele järgmise kirja: 
[---] Teatan Teile oma tervisest, olen ikka endiselt haige. Haiglas olen kaks kord olnud 20 dets - 30 jaan. 31. jaan 19 veebr. Töö mis pooleli jäi on pooleli kui tervis lubab jätkan, olen kogund umbes 15 matuse ja surnuaiapüha laululehte. [---] (EFAM, RO)

Edasi kirjeldas Mary Kaasik lähikondlaste surmasid: ta on hiljaaegu matnud mehe ema, oma venna ning lähipäevil tuleb matta vähki surnud õde ja lisas:

[---] Kallasto on hea tervise juures, töötab endiselt. Lootsin et 1. maiks olen terve, aga ei, enesetunne ikka on vähe parem. Jalutan kodu ümbruses. Wanasõna ütleb: "Küll suvi silub, jaan teeb jalad alla, ka mina loodan sellele”. [---] (EFAM, RO)

Osakonnalt tuli vastus kaastundega kaotustele ja kannatustele, ning anti teada, et Selma Lätt on väga haige, aga nü̈̈d keerab siiski paremuse poole. Järgmises kirjas juulis 1969 mälestas Mary omakorda Selma Lätti. Ta andis teada, et jätkab enda ravimist, on veidi paranenud ja loodab varsti tööd jätkata. Kirjale vastates soovitas Mall Proodel (Hiiemäe) Kaasikul puhata ja jõudu koguda. 1969. aasta lõpus teatas Mary Kaasik, et on nii palju tervemaks saanud, et jõuab sulepead hoida, kuid käimine on vilets ning ravi kestab endiselt edasi.

1969. aasta detsembris saatis julgustava kirja Mary Kaasikule Mall Proodel:

[---] Saime jälle head materjali. Palju tänu. Hoidke ikka tervist, see on inimese kallis vara. [---] (EFAM, RO)

Juunis 1970 saabus Kaasikult ja Kallastolt kiri seoses rahvaluulekogujate seminariga:

[---] Tervitame Rahvaluule peret ja kõiki seminarist osavõtjaid. Soovime head edu, jõudu ja tervist edaspidiseks. Teatan, kurbusega, et haiguse halvenemise tõttu ei saa Teiega koos viibida. Kuid mõttes elame kaasa. [---] (EFAM, RO)

1970. aasta novembris kirjeldas Mary Kaasik taas oma tervislikku olukorda:

[---] Kogume viletsat viisi, nagu isegi viletsad oleme. Olen ikka haige, elan ja liigun. Loodan talvel tervist paranema. Iga päev tarvitan rohte. Liikuda on raske nagu varemki. [---] (EFAM, RO)

Muuhulgas andis Mary Kaasik teada, et Gustav Kallastoga juhtus septembris õnnetus - ta lasi höövlimasinaga vasaku käe kolmel sõrmel küüned ja otsad maha:

[---] nü̈̈d on juba terved ja käib endiselt. Oktoobris suri vend tal. Järgmine kuu saadame paar-kolm vihikut kui elu sees töötame edasi. [---] (EFAM, RO) 
Sellele kirjale saatis juba novembris vastuse Ingrid Rüütel:

[---] Aitäh kirja eest, kuigi see oli nii ootamatult kurb. Loodame siiski, et Kallasto saab oma õnnetusest pikapeale üle ja et Teie enesegi tervis aegamööda paraneb. [---] Soovime teile mõlemile kõigest südamest head tervist ja õnnelikku käekäiku edaspidiseks. [---] (EFAM, RO)

Detsembris 1970 laekus Mary Kaasikult vastus. Ta tänas rõõmustava kirja eest, mille oli Ingrid Rüütlilt saanud:

[---] Kallasto paranenud, tänab kaastunde eest. Mina ikka olen haiglane kuid natuke paranenud. Talvel loodame rohkem töötada. Mul on käimine raske. [---] (EFAM, RO)

1971. aasta aprillis teatas Mary Kaasik, et nii tema kui Gustav Kallasto on rahvaluulekorrespondentide seminarist osa võtmas. Juba mais saatis ta aga kirja, kus kurtis, et jäi pärast kaastööliste seminari grippi:

[---] Ka see viga hakkab juba mööduma. Kuid varsti võib jälle pisi tasa tööle hakata. Suvel kergem liikuda. Ega me Teid ei unusta. Head tööd ja tervist edaspidiseks. [---] (EFAM, RO)

Juuni alguses 1971 kirjutas Mary Kaasik, et vahepealne Tartus käik oli tervisele kasulik, ta on kirjutanud laule ja muud materjali ning loodab külasse koguma minna. Juuni lõpus 1971 andis ta kogutut ära saates kaaskirjas teada, et tervisel pole väga viga.

1971. aasta septembris kirjutas ta aga, et saadab materjali, mida tal õnnestus ainult kodus olles kirjutada - ta viibis augustikuus haiglas, kus jäi enda sõnul veel haigemaks ning on seni toas liikunud:

[---] Täna ja eila käisin juba väljas. Loodan paranemist - seekord. ... Kallasto tervisel ei ole viga. [---] (EFAM, RO)

Sellele kirjale tuleb Olli Kõiva poolt vastus, kus ta ergutab Mary Kaasikut mitte üle pingutama, kui tervis hea pole:

[---] Haiglas mõjub ka teiste hädade nägemine halvasti. [---] (EFAM, RO)

Veebruaris 1972 kommenteeris Mary Kaasik oma tervist taas:

[---] Vabandan väga, et suure hilinemisega vastan. Parandasin tervist ja tunnen praegu päris hea tervise juures olema. Hakkan uue jõuga jälle laule ja kombeid kirjutama mis pooleli on. Viimase kirjutamisega ruttasin. Arvasin et enam üldse ei parane. Kallasto on ka tervise juures. [---] (EFAM, RO) 
Septembris 1972 teatas Mary Kaasik, et nad mõlemad Gustav Kallastoga on elus ja terved, ta enda tervis paranes, kuid Kallasto oli neli nädalat haiglas. Sellele vastas Mall Hiiemäe enda tervist kommenteerides, et ka tema on elus ja terve ning pärast pikka eemalolekut tööl tagasi.

Novembris 1972 kirjutas Mary, et on tegelenud surmaennustuste küsitluskavaga ning tahab detsembri lõpuks töö ära saata. Ta teeb paranenud tervise tõttu juba koduseid töid ning loodab suvel (järgmisel aastal) kaugemal koguda. Lisaks teatas ta mitte vähem olulise uudise, et neil on nüüd peres uus Žiguli, nii et saab teha kaugemaid sõite, ja isegi telefon.

1972. aasta lõpus võttis Mary Kaasik aasta kokku nii:

[---] Saadame käesoleva aasta tööd. Ei jõudnud varem sest kodused tööd on ka minu hooleks. Kui tervis nii edasi siis loodame rohkem töödada. [---] (EFAM, RO)

Lisaks mainis Mary Kaasik selles kirjas esmakordselt, et on teinud kaastööd ka etnograafiamuuseumile ${ }^{4}$.

1973. aasta juunis võis Mary Kaasik teatada, et nad mõlemad Gustav Kallastoga on tervise juures, ehkki kevadel oli ta kopsupõletikuga Kiviõli haiglas:

[---] Sain väga tugeva ja hea ravi. Nüüd on tervis tunduvalt parem, söögiisu hea. Käia saan ka päris hästi. [---] (EFAM, RO)

Oktoobris 1973 võib osakonna poolt saadetud kirja ärakirjast mõista, et Mary Kaasik on osa saadetud materjalist kirja pannud haiglas olles ning osa laekunud, kuid mitterahvapärasest laulusaadetisest on jäetud kirjavahetuskogusse. 1974. aasta lõpus mainis Mary Kaasik kirja algul uuesti, et mõlemad kogujad on elus ja tervise juures ning saadavad laule ja mõisajutte, ühtlasi on nad kogunud pulmakombeid, kuid nende saatmise jätab 1975. aastaks.

Harukordselt saatis 1975. aasta lõpul arhiivile postkaardi Gustav Kallasto, kes teatas pühadesoovidele lisaks, et tema tervis on jälle päris hea.

Gustav Kallasto kirjutas taas arhiivile 1976. aasta septembris, sest Mary Kaasik viibis maal. Ta jagas infot varasemates kirjades kõne all olnud lauluklade kohta ning lisas:

[---] Katsuge minu kirjast aru saada olin kuus nädala haiglas käsi on nii raske. [---] (EFAM, RO)

Ka 1976. aasta oktoobris kirjutas arhiivile Gustav Kallasto, kurtes, et on veel haige, jõud saab otsa ning ta on jätkuvalt arstide valve all, tervis on visa tagasi tulema ja käsi väsib kirjutades. 1976. aastaga lõppes ühtlasi selle kogujatetandemi kirjavahetus. Viimane materjalisaadetis saabus registrite järgi 1974, neile järgnesid mitu aastat vaid vastastikkused uusaasta- ja muud tervituskaardid. 
Mary Kaasikult rohkem kirju ei laekunud, ta suri oktoobris 1977. 1979. aastal suri Gustav Kallasto, käsikirjakogus on säilitatud tema mälestuskaart (RKM II 336, 120/1).

Toonane kogumispõhimõte - oma kommentaare materjalile mitte lisada takistab tänastel folkloristidel mõningal määral kogujate teadmiste ja konteksti osas järelduste tegemist ning kogutud materjali koguja/informandiga isiklikumat seostamist. Seda põhimõtet tuleb muidugi vaadata tolle aja kontekstis, lisakommentaare ei peetud siis väärtuslikuks. Seda enam on huvitav jälgida, et kommentaarid nii materjalidesse kui peamiselt kirjavahetusse siiski sisse tulid, sealjuures nii isiklikul teemal kui seda on enda tervis.

Virumaa kaastöölised Mary Kaasik ja Gustav Kallasto olid ühed neist, kes kogusid rahvameditsiinilist materjali 1959. aasta küsitluskava järgi. Kaasiku ja Kallasto kogutud materjali koguhulka hinnates ei ole rahvameditsiinilise materjali osakaal eriti suur, kuid see on üks teemadest, mille puhul panid Mary Kaasik ja Gustav Kallasto kirja ka isiklikke teadmisi või üleelamisi. Kirjavahetusest selgub, et nende terviseprobleemid leidsid kajastamist nii kirjavahetuses kui ka pärimusliku materjali pisikommentaaridena, seejuures oli Mary Kaasik altim oma probleeme jagama ning tema oli ka see, kes kirjutas folkloristidele mõlema koguja eest, sh tervisest.

\section{Kokkuvõtteks}

Riikliku Kirjandusmuuseumi rahvaluule osakonna nõukogudeaegse kirjavahetuskogu põhjal võib järeldada, et kaastööliste jaoks on isiklik tervis olnud kirjades oluliseks teemaks. Probleemid tervisega oli oluline takistus kogumistööl, kokkutulekutele ja seminaridele sõitmisel; teated iseenda, lähedaste või ka teiste kogujate või informantide (vaimsest ja füüsilisest) tervisest on osa kaaskirja sisust. Teisalt tõuseb tervis esile ka folkloristide kirjades, kes jagasid kaastöölistele sõnumeid enda või kolleegide kohta, kui selleks oli vajadus - pikem haigus, laste sünd, töötajate surm. Ühtlasi tekitab tervisetemaatika huvitava dialoogiketi kaastöölise ja folkloristi vahel, kus terviseküsimuste kaudu üksteist julgustati või ka manitseti enda eest hoolitsema. Nii on üsnagi isiklik elu kõrvuti praktiliste kogumis- ja arhiveerimistööd puudutavate nõudmistega.

Tervise kohta võib kirjavahetusest seega andmeid leida palju. Terviseteemalised sõnumid on isiklikud ja usalduslikud, valdaval osal kaastöölistest ei olnud sisemisi takistusi enda tervisest kirjutamisel ning ka folkloristide tervise järele pärimisel. Kirja teel jagatu võimaldas enda tühjaksrääkimist ja murede jagamist ning pakkus tõenäoliselt meelekergendust. Teisalt näitab see kaastööliste missioonitunnet - ka haigena mõeldi sellele, et jõuaks jälle koguma. 


\section{Tänusõnad}

Artikli valmimist on toetanud Eesti Rahvakultuuri Keskus (Virumaa pärimuskultuuri toetamise programm), Eesti Kirjandusmuuseumi projekt EKM 8-2/20/2, Haridus- ja Teadusministeerium (EKKD65) ning Euroopa Liit Euroopa Regionaalarengu Fondi kaudu (Eesti-uuringute Tippkeskus).

\section{Kommentaarid}

1 Artikli ilmumise ajal on kogu pagineerimisel ja andmestik täpsustamisel.

${ }^{2}$ Kogumine viidi läbi 1959. ja 1964. aastal, andmestik on leitav köites RKM II 207.

3 Saadetud vastus (köide RKM II 111) on üks väheseid, kus keskenduti ainult rahvameditsiinilise andmestiku kogumisele.

4 Mary Kaasiku kaastööd Etnograafiamuuseumile olid põllundus ja kangakudumine (1971), tuletegemine (1974), andmed kella ja ajaarvamise kohta (1975).

\section{Arhiiviallikad Eesti Kirjandusmuuseumis}

EFAM - Eesti folkloristika ajaloo materjalid Eesti Rahvaluule Arhiivis

EFAM, RO - Eesti folkloristika ajaloo materjalid EKM Eesti Rahvaluule Arhiivis, Riikliku Kirjandusmuuseumi rahvaluule osakonna kirjavahetus korrespondentidega

EFAM, RKM - Korrespondendid. Kaardid

RKM II - Riikliku Kirjandusmuuseumi rahvaluulekogu (1940-1994)

\section{Kirjandus}

Annuk, Eve 2004. Keha ja haigus Ilmi Kolla kirjades ja luuletustes. Ariadne Lõng 1/2, lk 43-57.

Annuk, Eve 2006a. Imbi Kolla ja tema aeg. Biograafilise lähenemisviisi võimalusi nõukogude aja uurimise kontekstis. Dissertationes Litterarum et Contemplationis Comparativae Universitatis Tartuensis 3. Tartu: Tartu Ülikooli Kirjastus (http://www. digar.ee/id/nlib-digar:4121 - 28. oktoober 2020).

Annuk, Eve 2006b. Uurija rollist ja eetikast biograafilise uurimise kontekstis Ilmi Kolla kirjavahetuste näitel. Kõiva, Mare (koost). Võim ja kultuur II. Tartu: Eesti Kultuuriloo ja folkloristika Tippkeskus, Eesti Kirjandusmuuseum, lk 149-170.

Gorsič, Ave 2017. The Life Behind Folklore Collecting: August Martin as a Correspondent of the Folklore Archives. Laime, Sandis; Bula, Dace (toim). Mapping the History of Folklore Studies: Centers, Borderlands and Shared Spaces. Newcastle upon Tyne: Cambridge Scholars Publishing, lk 73-84. 
Gorsič, Ave 2018. The Position of Folk Belief in Estonian folkloristics During the Soviet Era. Harvilahti, Lauri \& Kjus, Audun \& Scott, Fredrik \& O'Carroll, Cliona \& Treija, Rita \& Österlund-Pötzsch, Susanne (toim). Visions and Traditions. Knowledge production and Tradition Archives. FFC 315. Helsinki: Suomalainen Tieteakatemia, lk 122-140.

Hinrikus, Rutt \& Kirss, Tiina Ann (koost) 2019. Eesti Elulookirjutus. Antoloogia. Kirjad, päevikud, mälestused \& elulood. Tartu, EKM Teaduskirjastus.

Kask, Mihkel \& Villako, Kaljo 1959. Rahvameditsiini andmete kogumise vajalikkusest. Nõukogude Eesti Tervishoid 4. Tallinn: Ajalehtede-ajakirjade Kirjastus, lk 52-59.

Kirss, Tiina Ann, 2019. Kirjad. Hinrikus, Rutt \& Kirss, Tiina Ann (koost). Eesti Elulookirjutus: Antoloogia. Kirjad, päevikud, mälestused \& elulood. Tartu, EKM Teaduskirjastus, lk 221-226.

Kikas, Katre 2017. Rahvaluulekogumine epistolaarses kontekstis. Helene Maaseni kirjad Jakob Hurdale. Keel ja Kirjandus 4, lk 272-290.

Kleinmann, Arthur 1988. The Illness Narratives. Suffering, Healing and the Human Condition. New York: Basic Books.

Korb, Anu 2013. Rahvaluule osakonna Siberi kaastöölise Rosalie Ottessoni ja teaduritearhivaaride dialoog aastatel 1969-1976. Mäetagused 54, lk 7-26 (doi: 10.7592/MT2013.54. korb).

Korb, Anu 2015. Roosi Siberi lood. Eesti asundused VII. Tartu: EKM Teaduskirjastus.

Lätt, Selma 1962. Aruanne rahvaluulekogumisest 1.I - 31.XII 1961. Tampere, Herbert \& Rüütel, Ingrid (toim). Rahvapärimuste koguja 3. Tartu: Eesti NSV TA Fr. R. Kreutzwaldi nim Kirjandusmuuseum, lk 51-57.

Lätt, Selma 1965. Aruanne rahvaluulekogumisest 1.I 1962 - 31.XII 1963. Tampere, Herbert \& Krikmann, Arvo (toim). Rahvapärimuste koguja 4. Tartu: Eesti NSV TA Fr. R. Kreutzwaldi nim Kirjandusmuuseum, lk 89-96.

Lätt, Selma 1968. Aruanne korrespondentide kogumistööst 1965. aastal. Tampere, Herbert \& Liiv, Ellen (toim). Rahvapärimuste Koguja 6. Tartu: Eesti NSV TA Fr. R. Kreutzwaldi nim Kirjandusmuuseum, lk 78-80.

Oras, Janika 2008. Viie 20. sajandi naise regilaulumaailm. Arhiivitekstid, kogemused ja mälestused. Eesti Rahvaluule Arhiivi Toimetused 27. Tartu: Eesti Kirjandusmuuseumi Teaduskirjastus.

Rüütel, Ingrid 1962. 11000 lehekülge täienduseks meie rahvaluulepärandile. Rahvapärimuste Koguja 3. Tartu: ENSV TA Fr. R. Kreutzwaldi nim. Kirjandusmuuseum, lk 63-70.

Stanley, Liz 2004. The Epistolarium: On Theorizing Letters and Correspondences. Auto / Biography 12, lk 201-235 (doi: 10.1191/0967550704ab014oa).

Tampere, Herbert 1962. ENSV TA Fr. R. Kreutzwaldi nim. Kirjandusmuuseumi rahvaluule-alased ekspeditsioonid 1961. aastal. Tampere, Herbert \& Rüütel, Ingrid (toim). Rahvapärimuste koguja 3. Tartu: Eesti NSV TA Fr. R. Kreutzwaldi nim Kirjandusmuuseum, lk 58-60. 
Tupits, Ave 2009. Käsitlusi rahvameditsiinist: mõiste kujunemine, kogumis- ja uurimistöö kulg Eestis 20. sajandil. Dissertationes Folkloristicae Universitatis Tartuensis 13. Tartu: Tartu Ülikooli Kirjastus (http://hdl.handle.net/10062/14290 - 28. oktoober 2020).

Viires, Ants 1975. Rahvameditsiini uurimine päevakorral. Keel ja Kirjandus 6. Tallinn: Perioodika, lk 380-382.

\title{
Summary
}

\section{Mary Kaasik and Gustav Kallasto's folklore collection and correspondence}

\author{
Ave Goršič \\ Research Fellow \\ Estonian Folklore Archives, Estonian Literary Museum \\ ave.gorsic@folklore.ee
}

Keywords: correspondence, data collection, (folk) medicine, health, Soviet period

The broader source material for this article is the Soviet-era correspondence of the Folklore Department (FD) of the Fr. R. Kreutzwald State Literary Museum, today the Estonian Folklore Archive of the Estonian Literary Museum. This collection consists of letters and postcards of nearly 400 people, as well as transcripts of the FD staff letters to their contributors. The total volume amounts to roughly 4,000 pages and mainly covers the period from the 1950s to the first half of the 1990s. The article also discusses the contributions of Virumaa correspondents Mary Kaasik and Gustav Kallasto to the department, more specifically the folk medicine material collected by them, and focuses on Kaasik and Kallasto's correspondence with the department, with the main emphasis on the personal health issues in their letters.

Mary Kaasik and Gustav Kallasto were among those who collected folk medicine material according to the 1959 survey plan, assembled in co-operation with the folklorists and medical doctors. Assessing the total amount of material collected by Kaasik and Kallasto (over 3300 pages), the folk medicine material is not very large (over 200 pages), but it is one of the topics in which Mary Kaasik and Gustav Kallasto wrote down personal knowledge or experiences. The correspondence shows that their health problems were constantly reflected both in their letters and as short comments among traditional folk medicine material. Mary Kaasik was more inclined towards sharing her problems and personal knowledge and was the one who wrote to the department on behalf of both collectors.

In general, it is concluded that personal health has been an important topic in the letters of the contributors to the folklore department. Health problems were a major obstacle to commuting and attending seminars; so messages about the health of oneself, one's relatives or other collectors or informants are part of the content of the letters. On the other hand, health also comes to the fore in the letters of folklorists, who in turn 
informed their contributors about their own or their colleagues' health, if deemed necessary. At the same time, writing about health issues creates an interesting dialogue thread between the correspondents and the folklorists, with mutual encouragement and pleas to take care of one's health. Thus, a rather personal life goes hand in hand with the practical requirements stated in letters on collecting and archiving.

Thus, much data on health can be found in the department's correspondence. Healthrelated messages are personal and trusting, the majority of correspondents did not have internal obstacles to share their health worries and to enquire for folklorists' health. It meant sharing problems and probably provided some well-deserved mental relief. On the other hand, these kinds of letters also show the correspondents' sense of mission - even when they were off sick, they were eager to get back to the field again.

Ave Goršič kaitses 2009. aastal Tartu Ülikoolis doktoritöö "Käsitlusi rahva-meditsiinist: mõiste kujunemine, kogumis- ja uurimistöö kulg Eestis 20. sajandil". Ave Goršič on Eesti Kirjandusmuuseumi Eesti Rahvaluule Arhiivi teadur, tema uurimisteemadeks on folkloristika ja folklooriarhiivide ajalugu ning rahvameditsiin. Viimastel aastatel on ta osalenud folklooriarhiivide koostöövõrgustikes, olles praegu SIEF-i arhiivide töörühma kaasesimees.

Ave Goršič defended her doctoral dissertation titled Aspects on Folk Medicine: Developing of the Definition, Data Collecting and Research in Estonia in the 20th Century at Tartu University in 2009. Her research topics have included the history of folkloristics and folklore archives and folk medicine. Goršič is Research Fellow at the Estonian Folklore Archives of the Estonian Literary Museum. In recent years, she has been involved in initiatives to connect folklore archives, currently being a co-chair of the SIEF Working Group on Archives.

ave.gorsic@folklore.ee 